\title{
ZDROWY/A? CHORY/A? KATEGORIA ZDROWIA I CHOROBY PSYCHICZNEJ W OCZACH OSÓB Z DOŚWIADCZENIEM KRYZYSU PSYCHICZNEGO ORAZ NOWA ROLA EKSPERTA PRZEZ DOŚWIADCZENIE (EX-IN) W SYSTEMIE OPIEKI ZDROWOTNEJ I POMOCY SPOŁECZNEJ
}

\begin{abstract}
Healthy or ill? The categories of mental health and mental illness in the perspective of individuals with the experience of a mental health crisis and the new role of the expert by experience in the mental health and social welfare system
\end{abstract}

The article presents the results of qualitative research on ways of perception of the categories of mental health and illness by individuals with the experience of psychotic and psycho-affective disorders in the context of their recovery process. Moreover, the author puts an emphasis on describing one of the strategies of dealing with the stigma of mental disorder, which translates itself into a new social and professional role of the expert by experience (EX-IN).

Key words: mental health, mental illness, destigmatisation, recovery, expert by experience (EX-IN)

\section{Wprowadzenie}

Ponowoczesna rzeczywistość konfrontuje człowieka z napływem zmian, których kierunki są trudne do przewidzenia w sieci powiązań globalnego świata. Poprzez swe cechy, takie jak zmienność, płynność, fragmentaryczność, materializacja czy ekonomizacja, ponowoczesność przynosi wciąż nowe wyzwania i zagrożenia dla zdrowia psychicznego, które jest ważną sferą przekładającą się na funkcjonowanie człowieka w społeczeństwie. Dobrostan psychiczny stanowi istotną część modeli zdrowia oraz element różnych jego definicji (por. Tobiasz-Adamczyk 2000: 21-32). To zaburzenia somatyczne traktuje się jednak jako naturalną część życia, podczas gdy zaburzenia psychiczne wciąż wiążą się z uczuciem wstydu i lęku oraz stygmatyzacją.

Współcześnie jesteśmy świadkami wyraźnego wzrostu zaburzeń i chorób psychicznych, będących obciążeniem dla jednostki i całych populacji. O powadze kwestii związanych 
z zaburzeniami psychicznymi w Polsce świadczy badanie EZOP dotyczące stanu zdrowia psychicznego Polaków (Kiejna, Piotrowski, Adamowski, Moskalewicz, Wciórka, Stokwiszewski, Rabczenko, Kessler 2015). Zaburzenia psychiczne mogą prowadzić do znacznych niepełnosprawności, a czasem także wpływać na przedwczesną umieralność, w tym na samobójstwa. Wiele osób doświadczających zaburzeń psychicznych cierpi z powodu dyskryminacji, naruszenia praw człowieka czy ubóstwa. Pozbawione są one możliwości życiowych przysługujących osobom mieszczącym się w tak zwanej normie psychicznej. Powrót do traktowania ich jako pełnowartościowych członków społeczeństwa może odbyć się dzięki sprawnie działającemu systemowi opieki i rehabilitacji, a także holistycznemu postrzeganiu człowieka, w którym wymiar somatyczny łączy się z psychiką.

Dotychczas wiele badań i analiz z zakresu socjologii i psychiatrii koncentrowało się na zagadnieniu postaw wobec osób chorujących psychicznie z perspektywy ich stygmatyzującego wpływu oraz w wymiarze społecznego dystansu wobec chorych (np. Szpunar 2009; Wciórka, Wciórka 2008; Williams 2008). Niniejszy artykuł uzupełnia natomiast te rozważania o prezentację sposobu postrzegania zdrowia i choroby psychicznej przez osoby cierpiące na zaburzenia psychotyczne i psychoafektywne w kontekście ich procesu odzyskiwania zdrowia (recovery). Takie ujęcie tematu przybliża cele i dążenia pacjentów $\mathrm{w}$ procesie leczenia, a także kładzie nacisk na znaczenie ich indywidualnych działań w osiąganiu zdrowia. Opracowanie to wyrasta zatem z tradycji niemedykocentrycznej orientacji badawczej w socjologii medycyny, koncentrującej się na społecznej koncepcji choroby i dowartościowującej perspektywę laika (osoby niebędącej profesjonalistą medycznym) oraz rolę jego aktywności, a zwłaszcza decyzyjności i sprawstwa, w chorobie przewlekłej (por. Freidson 1970; Strauss, Glaser 1975). W związku z tym zwrócę szczególną uwagę na jeden ze sposobów radzenia sobie ze stygmatem w postaci zaburzenia psychicznego, który realizuje się poprzez podjęcie nowej roli społecznej i zawodowej jako ekspert przez doświadczenie (EX-IN). Wpisując się w nurt interakcjonizmu symbolicznego, artykuł przynosi zatem refleksję nad stygmatem i jego skutkami z punktu widzenia osoby stygmatyzowanej. Przywołując argumenty Alvina Gouldnera odnośnie do przyjmowania perspektywy tzw. dołów społecznych, podejście takie uznaje się za pożyteczne, gdyż „Zazwyczaj informacje na ten temat są ogólnie mało znane szerokiej publiczności, ale także socjologom" (Gouldner 1970, za: Czykwin 2008: 42). Podejście to stanowi również realizację postulatów socjologii humanistycznej wyrażających się w rozumieniu „subiektywnych znaczeń i sensów nadawanych różnym zjawiskom oraz procesom społecznym przez działające jednostki” (Czykwin 2008: 43), nawiązując do rozumienia motywacyjnego Maxa Webera czy współczynnika humanistycznego Floriana Znanieckiego.

\section{Perspektywa badawcza i inspiracje teoretyczne}

Materiał empiryczny, do którego odwołuję się w tym artykule, został zebrany w 2017 roku w związku z realizacją indywidualnego projektu badawczego, przeprowadzonego na użytek pracy magisterskiej pod tytułem Postawy społeczne wobec osób doświadczających 
zaburzeń psychicznych i ich znaczenie dla procesu zdrowienia - podejście socjologiczne. Celem badania było pokazanie znaczenia właściwej postawy społecznej wobec osób dotkniętych kryzysami psychicznymi i potrzeby pogłębiania świadomości społeczeństwa na temat wpływu (pozytywnego bądź negatywnego) postaw na to, co dzieje się z osobą chorą. Termin „właściwy” określa taką postawę, która sprzyjałaby zdrowieniu czy też dobrostanowi pacjenta, rozumianemu jako możliwość powrotu do satysfakcjonującego funkcjonowania w społeczeństwie. W niniejszym opracowaniu jednak koncentruję się głównie na doświadczeniach respondentów związanych z chorobą psychiczną i ich powrotem do zdrowia.

$\mathrm{W}$ analizach związanych ze wspomnianym projektem badawczym poruszałam kwestie stygmatyzacji oraz sposobu rozumienia przez respondentów zdrowia i choroby psychicznej, co wiąże się ze znaczeniem, jakie nadają oni chorobie w swoim życiu. Badania miały charakter jakościowy i opierały się na przeprowadzeniu pogłębionych wywiadów swobodnych z 11 osobami dorosłymi z doświadczeniem zaburzeń psychotycznych i psychoafektywnych oraz 8 specjalistami z zakresu zdrowia psychicznego ( 4 psychologami psychoterapeutami, 3 lekarzami psychiatrami, 1 pielęgniarką środowiskową). Technikę uzupełniającą badania stanowiła obserwacja środowiska pacjentów w trakcie czterech spotkań zorganizowanych dla nich i ich rodzin z ekspertami przez doświadczenie (EX-IN) w Zespole Leczenia Środowiskowego przy Centrum Psychiatrii im. dra Krzysztofa Czumy w Katowicach-Szopienicach. Jeżeli chodzi o grupę badanych z doświadczeniem zaburzenia psychicznego, to dobór celowy opierał się na kryterium charakterystyki klinicznej choroby. Wybrałam do badania osoby, które były hospitalizowane co najmniej raz w związku z epizodem psychotycznym lub schizoafektywnym z dekompensacją psychotyczną, ponieważ zaburzenia te uważane są za najsilniej stygmatyzujące (Świtaj 2005: 140). Warunkiem dodatkowym był czas zmagania się z chorobą, który ustaliłam na minimum 3 lata, licząc od pierwszego jej epizodu. Innym ważnym aspektem branym pod uwage było wycofanie objawów chorobowych w okresie badania (remisja), co konsultowałam z lekarzem psychiatrą prowadzącym danego pacjenta oraz psychoterapeutą. Pacjenci wykazywali zatem względnie unormowany stan zdrowia psychicznego. Jednocześnie grupa badanych charakteryzowała się zróżnicowaniem pod względem takich kryteriów, jak płeć, wiek czy miejsce zamieszkania.

Formułując problem badawczy, odwołałam się do podejścia teoretycznego zaproponowanego przez Brucéa G. Linka i Jo C. Phelan w pracy Conceptualizing stigma (Link, Phelan 2001), w której stygmatyzację przedstawiono jako wieloetapowy proces obejmujący współwystępowanie elementów, takich jak: (1) etykietowanie, (2) stereotypizacja, (3) poznawcze dystansowanie „my” i „oni” oraz (4) utrata statusu związana z dyskryminacją i wykluczeniem (Świtaj 2005: 138). Za B.G. Linkiem i J.C. Phelan przyjęłam zatem, że stygmatyzacja społeczna jest złożonym fenomenem, który ma swoje źródła również w innych zjawiskach.

U osób cierpiących na zaburzenia psychiczne stygmatyzacja i marginalizacja dotykają dwóch płaszczyzn - funkcjonowania jako osoba niepełnosprawna na poziomie społecznym oraz posiadania diagnozy zaburzenia psychicznego, co może prowadzić do 
samonapiętnowania (self sigma). Marginalizacja, której dokonują osoby względem siebie, jest skutkiem internalizacji i odniesienia do siebie negatywnych wyobrażeń społecznych, a także łączy się z antycypacją odrzucenia przez otoczenie społeczne. Zjawisko internalizacji zachodzi w trakcie procesu socjalizacji, kiedy ludzie uczą się określonych postaw wobec osób z zaburzeniami psychicznymi (Świtaj 2005: 139). Autostygmatyzacja, zwana „drugą chorobą", może być traktowana jako przeciwieństwo umacniania (empowerment) w procesie zdrowienia, w którym ważną rolę odgrywa osobiste zaangażowanie chorego w odzyskiwanie kontroli nad własnym życiem i leczeniem, połączone z wysoką samooceną i samoskutecznością (Świtaj 2005: 139).

Rozwijając zmodyfikowaną teorię stygmatyzacji, badacze zaobserwowali i wyodrębnili także następujące sposoby radzenia sobie ze stygmatem w chorobie psychicznej, istotne $\mathrm{z}$ punktu widzenia podejmowanej $\mathrm{w}$ artykule problematyki:

- zachowanie choroby w tajemnicy (secrecy);

- wycofanie społeczne (withdrawal), rozumiane jako ograniczenie kontaktów społecznych do wąskiego kręgu rodziny lub osób naznaczonych tym samym piętnem;

- edukowanie innych (education), czyli aktywna próba zmiany nieprzychylnych postaw (Link, Struening, Cullen, Shrout, Dohrenwend 1989, za: Świtaj 2005: 139).

Strategia edukowania innych, jak czynią to eksperci przez doświadczenie (ang. EX-IN, osoby z doświadczeniem kryzysu psychicznego działające na rzecz pacjentów i zdrowia psychicznego), przynosi refleksję, iż stygmat może przyjmować również wymiar pozytywnego wyróżnika, o którym wspomina Elżbieta Czykwin (2008). W takim względzie przestaje on być negatywnym naznaczeniem, a specyficzne okoliczności ujawnienia atrybutu pozwalają postrzegać osobę jako w pewnym sensie wyjątkową, szczególną czy oryginalną. Jest to jeden z mechanizmów destygmatyzacji.

Innym korzystnym wymiarem pojawienia się stygmatu może być proces przewartościowania dotychczasowego życia oraz zmiany celów tak, by docenić i dostrzec najważniejsze jego aspekty oraz relacje z osobami najbliższymi (Czykwin 2008). Okazuje się także, co potwierdziły przeprowadzone przeze mnie badania, że osoby ze stygmatem znajdują wiele współczucia i zrozumienia dla podobnych problemów u innych. Nasuwa się zatem stwierdzenie, że możliwość identyfikacji wywołuje poczucie solidarności z osobami stygmatyzowanymi, co rozwija chęć niesienia pomocy i służy wykreowaniu ideologii grupy własnej wokół stygmatu jako wyzwania kolektywnego.

Punktem zwrotnym w procesie stygmatyzacji, której produktem jest tożsamość negatywna, staje się więc przepracowanie problemu oraz powrót do tak zwanej tożsamości pozytywnej, określanej jako „przekonanie, że posiadamy zalety i uzdolnienia; że przynajmniej w pewnej mierze możemy wpływać na otoczenie i że porównania z innymi nie są dla nas niekorzystne. Ta "pozytywość» jest oznaką zdrowia psychicznego i dobrego przystosowania" (Malewska-Peyre 1992: 45, za: Czykwin 2008: 206). Przychylając się do słów polskiej uczonej, postrzeganie procesu zdrowienia w przypadku zaburzenia psychicznego wzbogacam odwołaniem do koncepcji salutogenezy i dynamicznego 
modelu zdrowia, zaproponowanej przez socjologa medycyny, Aarona Antonovsky'ego (1979). Podstawowym założeniem modelu salutogenicznego jest „definiowanie zdrowia i choroby jako kontinuum stanów od pełnego zdrowia do pełnej choroby, z najczęściej występującymi stopniowalnymi stanami pośrednimi, które należy rozumieć całościowo i dynamicznie jako ciągły proces równoważenia zasobów i wymagań w stosunku do wewnętrznych stresów psychologicznych i zewnętrznych stresorów społecznych" (Brodniak 2000: 176). Nie uznaje się zatem w tym podejściu dualistycznego rozróżnienia na zdrowie i chorobę, ale głoszony jest pogląd, iż każda jednostka znajduje się gdzieś na kontinuum pomiędzy idealnym zdrowiem a chorobą śmiertelną, zagrażającą życiu. Istotnym założeniem salutogenezy jest przekonanie o złożoności natury ludzkiej, która przekłada się na wymiary (fizyczny, psychiczny, społeczny i duchowy) zdrowia oraz ich zależność od różnych czynników i okoliczności (Piotrowicz, Cianciara 2011). Zdrowie i choroba tworzą znaczącą sferę jakości życia, w związku z czym działania na rzecz zdrowia daleko wykraczają poza opanowanie choroby i koncentrują się na zapewnieniu dobrego życia. Koncepcja salutogeniczna wydaje się szczególnie ważna w niniejszych rozważaniach z uwagi na to, że kładzie nacisk na kwestie pochodzenia zdrowia i czynniki sprzyjające zdrowieniu lub zachowaniu zdrowia. Składa się także na postawę w stosunku do kryzysu psychicznego jako naturalnego - niejako wpisanego w życie człowieka - stanu przejściowego, który można przezwyciężyć dzięki uruchomieniu zasobów jednostki, co wpływa na jej osobisty rozwój.

\section{Postrzeganie zdrowia psychicznego przez badanych}

Sposoby postrzegania zdrowia i choroby składają się na element poznawczy postaw, który może mieć przełożenie na ich pozostałe komponenty - behawioralny i emocjonalny - przyjmujące różny wydźwięk. W celu opisania, jak respondenci rozumieją zdrowie psychiczne, poproszono ich o wytłumaczenia tego pojęcia oraz o podanie jego elementów składowych. Sposób postrzegania zdrowia psychicznego pozwala zrozumieć cele oraz dążenia pacjentów w toku leczenia, a także to, jaką rolę pełnią ich własne postawy w dochodzeniu do zdrowia.

Przeprowadzone wywiady pokazały, że zdrowie psychiczne może być definiowane w bardzo różny sposób. Aczkolwiek w opinii badanych pacjentów jawi się ono przede wszystkim jako kategoria subiektywna, wielowymiarowa i procesualna. Respondenci opisywali zdrowie psychiczne jako stan dynamiczny i przekładający się na wiele aspektów życia, to jest: satysfakcjonujące funkcjonowanie $\mathrm{w}$ relacjach $\mathrm{z}$ innymi ludźmi i życie zawodowe, jakość życia, umiejętność przeżywania emocji, poczucie wpływu i kontroli, samoakceptację, samoświadomość, odpowiedzialność, niezależność, rozwijanie pasji i marzeń, samospełnienie czy kontakt z Bogiem. Nieostrość granic zdrowia psychicznego, na które może wpływać bardzo wiele czynników, a także jego procesualny charakter, zauważyli również badani specjaliści. Relacje badanych potwierdzają zatem zasadność 
założeń koncepcji salutogenezy, mówiącej o tym, że zdrowie to pewne kontinuum stanów. Poniżej przytoczę przykładowe wypowiedzi zawierające wspomniane elementy:

To powrót do normalnego życia, do normalnej aktywności, do życia zawodowego, to też miłość, spełnienie w tych obszarach relacji z ludźmi, z Panem Bogiem i radość z tego wszystkiego, co robię. Takie poczucie sensu (P.AK.08).

Na zdrowie psychiczne składają się Twój potencjał, możliwości rozwoju, interakcje międzyludzkie, zgodność z samym sobą w życiu, autonomia, słuchanie siebie, wgląd w siebie, możliwości decydowania, kompetencje, praca nad sobą, nad własnym rozwojem - to jest zdrowie psychiczne (P.MB.02).

Zdrowie to stan dynamiczny. To jest właściwie taka sinusoida, jak na wykresie. Zdrowie jest rodzajem harmonii między tymi odchyleniami w jedną i w drugą stronę, taką linią równowagi, uśredniającą te punkty odchyleń (P.AB.01).

Istotnym aspektem rozumienia zdrowia przez badanych okazała się świadomość posiadania wpływu na jego kształtowanie oraz poczucie odpowiedzialności za proces zdrowienia. Pacjenci pytani, co pomaga im w dochodzeniu do zdrowia, zwracali uwage na zaangażowanie, którym muszą się wykazać:

Dużo pracuję głównie sama nad sobą, nad moim sposobem myślenia, bardziej niż z pomocą innych (P.BN.10).

Wiedza, którą nabywam w procesie kształcenia, pozwala mi na samoświadomość. (...) Staram się taki mieć na to wpływ przez wiedzę, studiuję, daję radę, próbuję coś zmienić (P.KW.05).

Duży wpływ ma także kontakt ze specjalistami, (...) ale potem jest taka praca własna (P.MR.03).

Też zdrowy styl życia, dbanie o siebie i zdrowe odżywanie, uprawianie sportu. Pracuję nad tym (P.AB.01).

Poczucie odpowiedzialności za dochodzenie do zdrowia może też pociągać za sobą niestosowanie się do zaleceń lekarza i chęć poszukiwania najlepszych środków czy sposobów leczenia zgodnie z własnym odczuciem. Dotyczy to szczególnie rekomendowanej farmakoterapii.

U pacjentów zyskanie świadomości na temat znaczenia własnych działań może wpływać na zaangażowanie w proces leczenia i współpracę ze specjalistami czy rodziną. Jednak by możliwe stało się uzyskanie samoświadomości, autonomii, odpowiedzialności i decyzyjności, potrzebne jest przyzwolenie na to ze strony opiekunów i specjalistów, co - jak zaznaczyli badani - nie jest zadaniem łatwym.

(...) zdrowienie, powrót do decyzyjności, samostanowienia, powrót do rozwoju.

Autorka: I było to możliwe dzięki rodzinie przyjaciołom, lekarzom (...) (P.MB.02).

Nie dzięki temu. Dzięki temu, że oni otwierali mi możliwości, w których mogłem wybierać. Ten wybór, samostanowienie, decyzyjność to jest podstawa dla mnie zdrowienia. Niezależność (P.MB.02). 
W innym momencie rozmowy pacjent umacnia swoje stanowisko dotyczące znaczenia autonomii i samosterowności w procesie zdrowienia, łącząc je z możliwością kreowania rzeczywistości według własnej perspektywy:

Przed czymś uciekasz w swój własny, wykreowany świat. Ale musisz zrozumieć przed czym po to, żebyś Ty miał później możliwość kreowania rzeczywistości. Dla mnie świat nie jest takim, jakim go postrzegamy, tylko jakim go kreujemy. Jesteśmy twórcami świata (P.MB.02).

\section{Rozumienie kategorii choroby psychicznej przez badanych - wymiar pozytywny i negatywny}

Jeżeli chodzi o rozumienie kategorii choroby psychicznej, mogłam zauważyć, że respondenci zwracali uwagę na wiele jej wymiarów, które łączą się z procesem stygmatyzacji, a także z kwestią zmiany postaw w stosunku do zaburzeń psychicznych i osób nimi dotkniętych. Przy analizie zebranego materiału empirycznego wyodrębniłam dwa główne wymiary - pozytywny i negatywny.

W wymiarze negatywnym mieszczą się aspekty zaburzenia psychicznego odnoszące się do niesamowitego cierpienia pacjentów, ich poczucia odrealnienia, bólu, a nawet upokorzenia nim spowodowanego. W tym kontekście chorobę psychiczną można postrzegać jako piętno i wiązać z procesem stygmatyzacji, a także społecznej izolacji oraz osamotnienia.

Ja już tak się wycofałam do środka, że praktycznie nie było kontaktu ze mną. Oni [rodzina] nie wiedzieli o moich urojeniach, to siedziało w środku. (...) To, co ja przeżywałam, ten ból psychiczny, te urojenia, to (...) było straszne, tego nie można z niczym porównać i nawet trudno jest to opisać (P.AK.07).

Zdarza się, że choroba pociąga za sobą inne problemy społeczne, takie jak uzależnienie, co sprawia, że stygmat związany z problemem psychicznym nabiera wymiaru piętrowego:

Kolejną rzeczą jest to, że (...) zacząłem się wciągać w narkotyki. (...) Uzależnienie pojawiło się wtórnie, czyli najpierw była choroba psychiczna. Dla mnie uzależnienie było efektem samoleczenia. Zażywałem leki, które mi pomagały. Leki to były narkotyki, czyli substancje psychoaktywne (P.MB.02).

Przejmujący aspekt cierpienia ukazuje jeszcze inny badany, stwierdzając, że dla osób postronnych choroba może być wręcz niewidoczna, a osoba nią dotknięta mierzy się z przerażającymi myślami czy wyobrażeniami zupełnie sama:

Właściwie to wszystko tkwi w głowie, (...) nie przenika gdzieś tam w otoczenie. (...) Najgorsze są myśli, które pojawiają się we własnej głowie i z tym się człowiek mierzy podczas choroby, a dla postronnych często choroba jest „anonimowa”, niewidoczna (P.AB.01). 
Wypowiedź mężczyzny niesie przekaz, że większość cierpienia rozgrywa się w przeżyciach wewnętrznych osoby, dlatego też być może trudno jest otoczeniu społecznemu przyjąć postawę pełną współczucia.

Dla wielu badanych pacjentów choroba oznaczała życiową tragedię, bezwład oraz diametralne pogorszenie jakości życia, które trwało wiele lat. Byli zmuszeni zrezygnować z podjętej pracy lub studiów i nie mieli dostępu do żadnej drogi osobistego rozwoju. Inni z kolei komentowali warunki panujące w szpitalu, gdzie nie było miejsca dla intymności, a człowieczeństwo ukazywało się w całej swej krasie wraz ze wstydliwą fizjologią.

Pewnych rzeczy nie mogłam dokończyć, (...) bo choroba mi przeszkadzała. Na przykład bardzo pragnęłam skończyć studia na polonistyce. Przerwałam na czwartym roku (...). To wtedy choroba się ujawniła... (P.LB.11).

Brak intymności. Łazienka otwarta raz na jakiś czas, w południe. Jeśli nikt się w niej nie kąpał, to ja korzystałem. (...) I ogólnie dotyka się tam człowieczeństwa. Dotykamy człowieka takim, jakim jest. Wszystko jest na widoku (P.MB.02).

Niektórzy z badanych zwracali z kolei uwagę na głębsze znaczenie choroby psychicznej w ich życiu, tłumacząc, że była wyrazem czegoś, czego nie byli w stanie uzewnętrznić w żaden inny sposób (wyrażenie „niewyrażonego”), wyrazem obrony przed trudnymi do zaakceptowania aspektami życia, a wreszcie - wyrazem ucieczki przed zadaną im krzywdą $\mathrm{w}$ wykreowany przez siebie świat. Interpretowali ją również jako formę objęcia kontroli nad otaczającą rzeczywistością, a nawet wołanie o pomoc z powodu braku możliwości wyrażenia swoich potrzeb. Zwracali także uwagę, że czasem bywa kontynuacją pewnych niedoborów lub braków z wcześniejszych okresów życia.

Psychozę kreujesz po to, żeby uciec od czegoś, co się dzieje wokół Ciebie. Nie rozumiesz czegoś w sobie i zaczynasz kreować własne reguły gry, swoje własne perspektywy, to jest psychoza, to jest depresja, to jest mania (P.MB.02).

Popatrz się, jak własne doświadczenia mogą działać terapeutycznie. Czy nie mogę pomyśleć, że to była dla mnie jakaś forma ucieczki? Mój mózg zaczął inaczej pracować? Dlatego że to była konkretna reakcja na konkretne sytuacje, bardzo trudne sytuacje, traumatyczne (P.LB.11).

Ten kryzys, no... powstał na podstawie tego wszystkiego, co się działo w moim dzieciństwie. (...) To był taki jakiś brak umiejętności rozmowy, umiejętności społecznych. To bardzo wpłynęło na moją chorobę (P.EP.09).

Natomiast wymiar pozytywny choroby psychicznej wypływa ze zmiany sposobu myślenia pacjenta i odejścia od koncentrowania się na chorobie jako stygmacie, co należy do ważnych etapów procesu zdrowienia. Warto przy tym zaznaczyć, że spojrzenie pozytywne na chorobę możliwe jest po upływie pewnego czasu. Wymiar ten obejmuje postrzeganie choroby psychicznej jako punktu zwrotnego w życiu, który wnosi nowe wartości, pozwala odkryć wewnętrzny potencjał, a nawet może umożliwić poprawę 
jakości życia, tak że jawi się ono jako bardziej atrakcyjne niż przed zachorowaniem. Zaskakujący był fakt, że aspekt ten uwzględnili w swoich wypowiedziach wszyscy badani pacjenci. Poniżej zacytuję wypowiedzi najbardziej reprezentatywne:

Zastanawiałam się nieraz jak moje życie wyglądałoby, gdybym nie miała przeszłości naznaczonej chorobą psychiczną. Czy byłabym takim człowiekiem jak w tej chwili? Pełnym radości i wdzięczności do Boga za każdy dzień? (...) Widzę wyraźnie jak wydarzenia, spotykani ludzie, sytuacje służyły z jednej strony zdrowieniu, a z drugiej prowadziły do rozwoju osobowości. (...) Nauczyłam się pocieszać i rozumieć osoby chore, smutne, z problemami. (...) Jestem postrzegana przez otoczenie jako osoba zdrowa. A radość odzyskana smakuje zupełnie inaczej (P.AK.07).

Każde doświadczenie psychozy jest inne i z innym potencjałem się z niej wychodzi. (...) Choroba rozbudowała moją wrażliwość. Myślę, że spowodowało to, że jestem dzięki temu na kolejnym etapie rozwoju empatii (P.LB.11).

Ja widzę bardzo dużo pozytywnych rzeczy, bardzo dużą zmianę jakościową, jeśli chodzi o funkcjonowanie w świecie, o funkcjonowanie między ludźmi, odwagę do wyrażania swojego zdania, tak (P.EP.09).

Powyższe postrzeganie choroby wiąże się z psychologiczną koncepcją kryzysu, a właściwie jego dwojakiej roli w życiu człowieka. Z jednej strony zjawisko jawi się jako element stopniowo narastającej sytuacji zagrożenia lub nowych i zaskakujących okoliczności, często towarzyszy mu brak poczucia kontroli nad sytuacją bądź problemem oraz brak pomysłu na rozwiązanie trudności i silny stres (Skłodowski 2010: 10). $\mathrm{Z}$ drugiej strony może być traktowane jako moment przełomowy, przynoszący szansę na pozytywne rozwiązanie. Słowo „kryzys” wskazuje więc na charakter przejściowy i niejednoznaczny zjawiska, które przynosi możliwość zmiany, w przeciwieństwie do medycznego pojmowania "choroby” jako. disease (ang.), czyli odstępstwa od normy, przeciwieństwa zdrowia (Świętochowski 2010: 181-182). W niektórych sytuacjach choroba czy też kryzys psychiczny mogą być postrzegane jako konieczny lub twórczy element rozwoju osobowości, co głosiła teoria dezintegracji pozytywnej (Dąbrowski 1975).

Dla badanych pacjentów zaburzenie psychiczne nie mieści się w sztywnych definicjach, to stan odwracalny, jedno z wielu doświadczeń, jakie przynosi życie. Jest to doświadczenie uniwersalne, ponieważ może dotknąć każdego, nie pomijając wielkich tego świata. Co ważne, doświadczenie zaburzenia psychicznego pozwala na weryfikację wcześniej wytworzonego obrazu mentalnego choroby psychicznej, dzięki czemu może dojść do normalizacji choroby i modyfikacji w myśleniu o niej od stygmatyzującej kategorii ciekawego lub przerażającego marginesu do pojmowania jej jako jednego z elementów życia społecznego czy też ważnego problemu społecznego. Wspomniany sposób postrzegania choroby psychicznej sprzyja destygmatyzacji:

A w przypadku tych schorzeń psychicznych nie ma czegoś takiego, nie ma ostrej definicji i te pojęcia są po to, żeby się dało cokolwiek mówić na ten temat, a nie po to, żeby stwierdzać jakiś fakt. (...) Duże znaczenie, że lepiej się czuję, to było to, że ja tę chorobę wyrzuciłem z samego siebie. Choroba to nie jestem ja, to mi się tylko przydarzyło (...) (P.MK.04). 
Nie tylko ja mam tę chorobę. Zaczęłam się tym interesować, kto na nią choruje. Za dużo tam tych osób sławnych jest. Nawet Catherine Zeta-Jones, Van Damme, też na nią chorują... Więc będąc w tej czołówce światowych sław, nie czuję się samotna (P.KW.05).

Nie wstydzę się mojej choroby, bo to jest rzecz ludzka. Jest świadomość, że to się każdemu może przytrafić (P.MR.03).

Choroba psychiczna może być zatem uznana za kategorię wpływającą na jakość życia i obraz siebie, a także warunkującą motywację pacjentów do stawiania sobie celu, jakim jest zdrowie psychiczne. Wielu spośród respondentów wskazywało na istotną rolę, jaką pełni w procesie powrotu do zdrowia własna postawa wobec przeżywanego problemu i chęć współpracy ze specjalistami.

\section{Działalność ekspertów przez doświadczenie (EX-IN)}

U niektórych badanych doświadczenie choroby motywuje do podjęcia nowej roli społecznej i zawodowej - eksperta przez doświadczenie i edukatora. Dopełniając analizę wymiaru pozytywnego choroby, działalność tego typu stanowi strategię radzenia sobie ze stygmatyzacją. Służy przede wszystkim walce ze stereotypami na temat zaburzeń psychicznych, inkluzji społecznej oraz poprawie własnego wizerunku u osoby (jaźń odzwierciedlona), a w konsekwencji również - całościowego obrazu mentalnego Innych, postrzeganych w świadomości społecznej jako „chorzy psychicznie”:

Działalność w Fundacji eFkropka to jest spełnienie moich marzeń i wyjście z tego lęku. To jest coś, co bardzo chciałam, bo doszłam do wniosku, (... że ja nie chcę mieć kompleksów i że nie chcę się bać i chciałabym, żeby nie było właśnie wokół tego wszystkiego lęku i to się właśnie dzieje w ramach działalności w tej fundacji (P.EP.09).

Bodaj najpełniejszym obrazem wspomnianego wymiaru jest wypowiedź innej ekspertki przez doświadczenie, która pomaga osobom doznającym kryzysów psychicznych. Po upływie pewnego czasu badana spostrzegła, że przeżywane w czasie choroby cierpienie było darem i pozwoliło jej rozwinąć wrażliwość, empatię, umiejętność słuchania oraz chęć niesienia pomocy innym:

Dla mnie cierpienie jest darem, jak ja patrzę na to z dystansem. (...) Wiesz, co może dać choroba, taką większą wrażliwość na ludzi, którzy mają problemy, którzy są słabsi, umiejętność słuchania, taka chęć dzielenia się, niesienia pomocy, taki rozwój empatii. I to, że poznałam tylu wspaniałych ludzi właśnie. (...) Ta przyjaźń miała podstawy głębokie. To właśnie takie doświadczenie wspólnego piekła, które przeżyliśmy, to było coś, co połączyło mnie w taki wyjątkowy sposób z wieloma osobami. (...) I pojawiły się warsztaty EX-IN. (...) Ludzie sami w trakcie tych warsztatów wypracowują pozytywne perspektywy, oni uczą się patrzeć inaczej na to swoje traumatyczne doświadczenie, obiektywizują to, oni widzą, że inni też tego doświadczyli. (...) (P.AK.07). 
Co ważne, celem dzielenia się doświadczeniem dla ekspertów przez doświadczenie jest nie tyle przybliżanie cierpienia pacjentów psychiatrycznych, ile pokazanie, że zdrowienie i powrót do satysfakcjonującego funkcjonowania społecznego są możliwe. Skupianie się osoby z doświadczeniem kryzysu psychicznego wyłącznie na wymiarze cierpienia może stanowić poważną barierę w edukacji w zakresie zdrowia psychicznego:

Dużo jest takich osób, które skupiają się w swoich przekazach na negatywach, ile to spotkali się ze złym traktowaniem, jakie mieli straszne przejścia. To jest zbyt obciążające dla zwykłego człowieka (P.AK.07).

Podjęcie roli edukatora $w$ zdrowieniu wiąże się ze zmianą rozumienia rehabilitacji osób doświadczających zaburzeń psychicznych i położeniem nacisku na wsparcie oraz zasoby tkwiące w osobach chorujących. Przełomem w metodach rehabilitacji psychiatrycznej stały się pojawiające się w latach siedemdziesiątych XX wieku, początkowo w Stanach Zjednoczonych, a następnie w Europie Zachodniej, ruchy samopomocowe osób chorujących psychicznie. Stopniowo znaczenia nabierały bowiem koncepcje laika eksperta (lay expert) i pacjenta eksperta (expert-patient), które określają chorego jako „świadomy podmiot działający” (Skrzypek 2013: 55), biorący aktywny udział w procesach leczenia medycznego. Zjawisko to w przypadku chorób psychicznych przejawia się we wzroście liczby i zróżnicowania ruchów osób z doświadczeniem choroby, takich jak EX-IN (EXperienced-INvolvement), Hearing voices network czy Recovery movement, które wypracowały własne techniki i narzędzia mające umacniać zdrowie psychiczne. Obecnie funkcjonują one pod wieloma nazwami: „eksperci przez doświadczenie” (experts by experience), „ocaleni z psychiatrii” (survivors of psychiatry) czy „ekspacjenci” ((ex)users) (Bronowski, Chotkowska 2016: 15). Niewątpliwie zastanawia fakt, że przez wiele lat grupy te były odsuwane od głosu i procesu podejmowania decyzji w leczeniu. Wiązało się to zapewne z dominacją paternalistycznego modelu relacji lekarz-pacjent, w którym pomijano zdanie pacjentów, a decyzje o zasadach leczenia podejmowali właściwie wyłącznie specjaliści. Upodmiotowienie chorego i uwzględnienie jego roli jako osoby negocjującej kwestie zdrowotne z profesjonalistami, zgodnie z ideą „ludzkiego spotkania” (Tobiasz-Adamczyk 2002), stanowią przejaw humanizacji działań podejmowanych przez służbę zdrowia i pomoc społeczną.

Model EX-IN, stworzony w latach 2005-2006 dzięki porozumieniu specjalistów i ośrodków uniwersyteckich oraz klinicznych z Niemiec, Szwajcarii, Wielkiej Brytanii, Szwecji, Norwegii, Holandii i Słowenii, promuje włączenie wiedzy oraz doświadczeń osób dotkniętych kryzysem zdrowia psychicznego do systemu pomocy (Karaszewska, Kożuszek 2014: 3). Tym samym kładzie nacisk na umacnianie (empowerment) i rozwój osobisty pacjentów, angażując ich jako ekspertów poprzez doświadczenie we wsparcie zespołów terapeutów i innych specjalistów działających w różnego rodzaju placówkach, takich jak środowiskowe domy samopomocy, oddziały psychiatryczne czy mieszkania chronione. W tym względzie czerpanie z wiedzy ekspertów przez doświadczenie w odniesieniu do specyfiki zaburzeń psychicznych, sposobów radzenia sobie z objawami 
i oczekiwań pacjentów na temat otrzymywanej pomocy wydaje się nieocenione dla specjalistów podejmujących działania z zakresu rehabilitacji społecznej. Współdziałanie pracowników socjalnych z ekspertami przez doświadczenie wpisuje się $\mathrm{w}$ "podejście skoncentrowane na rozwiązaniach" (Podgórska-Jachnik, Pietras 2014), stosowane w pracy socjalnej z pacjentami psychiatrycznymi, jako że są oni motywowani do kreowania zmian najpierw we własnym życiu, a następnie w życiu innych osób doświadczających kryzysów psychicznych. Podejmowanie wspólnych inicjatyw rozbudza kreatywność i otwiera szanse na aktywność zawodową pacjentów w przyszłości, rozwijając mechanizm samowzmacniania oraz chroniąc przed fiksacją retrospektywną i funkcjonalną, czyli koncentracją na nieodwracalnych sytuacjach i bezskutecznych działaniach (Podgórska-Jachnik, Pietras 2014: 121). Współpraca ekspertów przed doświadczenie z pracownikami socjalnymi może zatem odbywać się na dwóch płaszczyznach - poprzez działania z zakresu psychoedukacji i poradnictwa oraz poprzez wzbogacanie umiejętności pracowników socjalnych we wspieraniu i towarzyszeniu podopiecznym w trudnych momentach. Pozwala to pracownikom socjalnym pełniej rozumieć istotne znaczenie własnego doświadczenia u osoby chorej i przekuwać zasób tkwiący w doświadczeniu choroby w motywację prowadzącą do zmiany.

W Polsce w ciągu ostatnich lat można zaobserwować rosnący wpływ tej formy pomocy i aktywizacji zawodowej osób z doświadczeniem choroby psychicznej. Za przykład może służyć projekt pod tytułem Nowy zawód: ekspert przez doświadczenie (EX-IN), którego realizacji podjęła się Fundacja Wspierania Rozwoju Społecznego „Leonardo” z Krakowa wraz z partnerami, w ramach Programu Operacyjnego Wiedza Edukacja Rozwój 2014-2020 zarządzanego przez Ministerstwo Rozwoju (http://fundacja-leonardo. pl/nowy-zawod/, dostęp: 20.02.2018).

\section{Podsumowanie}

Rosnący indywidualizm uwidaczniający się w społeczeństwie w erze ponowoczesnej nabiera dwoistego charakteru. $Z$ jednej strony może przyczyniać się do wzrostu poczucia osamotnienia i alienacji jednostki, $\mathrm{z}$ drugiej zaś może skłaniać do poszanowania prawa każdego człowieka do dokonywania wolnych wyborów, co w przypadku osób doświadczających problemów natury psychicznej przekłada się na dostosowanie leczenia do ich indywidualnych potrzeb. Istotne wydaje się zatem uwzględnienie głosu i zaangażowania pacjentów w następującej obecnie zmianie systemu leczenia psychiatrycznego w Polsce, by możliwe stało się upodmiotowienie jego beneficjentów. Ewolucja systemu ochrony zdrowia psychicznego powinna także zaistnieć wraz ze zmianą społecznej percepcji zaburzeń psychicznych i destygmatyzacją, nastawieniem na rozwój opieki środowiskowej, a także przy uwzględnieniu trendów humanistycznych w psychiatrii, psychoterapii i pracy socjalnej. Aktywny udział osób z doświadczeniem kryzysu psychicznego w systemie pomocy jako ekspertów przez doświadczenie jawi się jako niezwykle wartościowe rozwiązanie, które dostarcza również nowych danych jakościowych na temat specyfiki 
kryzysów psychicznych, przyczyniając się do rozwoju wiedzy naukowej w tym zakresie. Działalność w charakterze edukatora czy też instruktora zdrowienia jest szansą na pełniejszą aktywizację zawodową osób z doświadczeniem kryzysu psychicznego i okazją do rewaloryzacji cennej perspektywy użytkownika systemu w procesie leczenia. Promowanie humanistycznego podejścia specjalistów i otoczenia społecznego wobec osób doświadczających zaburzeń psychicznych przyczynia się do rozwoju systemu opieki, w którym pacjent nie „poddaje się" leczeniu, lecz podejmuje aktywną rolę i staje się równoprawnym partnerem specjalisty, biorącym odpowiedzialność za swój proces leczenia i zdrowienia.

\section{Bibliografia}

Antonovsky A. (1979). Health, Stress and Coping: New Perspectives on Mental and Physical Well-Being. Jossey-Bass Publishers, San Francisco.

Brodniak W.A. (2000). Choroba psychiczna w świadomości społecznej. Oficyna Naukowa, Warszawa.

Bronowski P., Chotkowska K. (2016). Nowe trendy w rehabilitacji osób chorujących psychicznie. „Niepełnosprawność - Zagadnienia, Problemy, Rozwiązania”, 3, 20: 11-20.

Czykwin E. (2008). Stygmat społeczny. PWN, Warszawa.

Dąbrowski K. (1975). Trud istnienia. Wiedza Powszechna, Warszawa.

Freidson E. (1970). Profession of Medicine. A Study of the Sociology of Applied Knowledge. London Harper and Row Publishers, New York-Hagerstown-San Francisco.

Fundacja Leonardo (2017-2019). Nowy zawód: ekspert przez doświadczenie (EX-IN); http:// fundacja-leonardo.pl/nowy-zawod/ (dostęp: 20.02.2018).

Karaszewska A, Kożuszek A. (2014). EX-IN we Wrocławiu, http://otwartydialog.pl/wp-content/ uploads/2014/08/EX-IN-Karaszewska-Ko\%C5\%BCuszek.pdf (dostęp: 20.02.2018).

Kiejna A., Piotrowski P., Adamowski T., Moskalewicz J., Wciórka J., Stokwiszewski J., Rabczenko D., Kessler R.C. (2015). Rozpowszechnienie wybranych zaburzeń psychicznych w populacji dorostych Polaków z odniesieniem do ptci i struktury wieku - badanie EZOP Polska. „Psychiatria Polska", 49, 1: 15-27.

Link B.G., Phelan J.C. (2001). Conceptualizing stigma. „Annual Review of Sociology”, 27: 363-385.

Link B.G., Struening E., Cullen F.T., Shrout P.E., Dohrenwend B.P. (1989). A modified labeling theory approach to mental disorders: An empirical assessment. „American Sociological Review", 54, 3: 400-423.

Piotrowicz M., Cianciara D. (2011). Teoria salutogenezy - nowe podejście do zdrowia i choroby. „Przegląd Epidemiologiczny”, 65: 521-527.

Podgórska-Jachnik D., Pietras T. (2014). Praca socjalna z osobami z zaburzeniami psychicznymi $i$ ich rodzinami. Centrum Rozwoju Zasobów Ludzkich, Warszawa.

Skłodowski H. (2010). Psychologiczne wyzwania kryzysu, w: H. Skłodowski (red. nauk.), Przedsiębiorczość i zarządzanie. T. 11, Z. 1. Psychologiczne wyzwania kryzysu: Człowiek w kryzysie - psychospoleczne aspekty kryzysu. SWSPiZ, Łódź: 9-22. 
Skrzypek M. (2013). Geneza, przedmiot i funkcje niemedykocentrycznej orientacji badawczej socjologii medycyny, w: W. Piątkowski (red. nauk.), Zdrowie i choroba w badaniach socjologicznych prowadzonych na Uniwersytecie Medycznym w Lublinie 1995-2013. Uniwersytet Medyczny w Lublinie, Lublin: 39-59.

Strauss A.L., Glaser B.G. (1975). Chronic Illness and the Quality of Life. The C.V. Mosby Company, Saint Louis.

Szpunar M. (2009). Odgrodzeni od świata poprzez bariery mentalne. Społeczne stereotypy i dystanse wobec osób chorych psychicznie, w: W. Muszyński, E. Sikora (red.), Pod wielkim dachem nieba. Granice, migracje i przestrzeń we współczesnym społeczeństwie. Wydawnictwo Adam Marszałek, Toruń: 309-320.

Świętochowski W. (2010). Choroba przewlekła jako sytuacja kryzysowa w systemie rodzinnym, w: H. Skłodowski (red. nauk.), Przedsiębiorczość i zarządzanie. T. 11, Z. 1. Psychologiczne wyzwania kryzysu: Człowiek w kryzysie - psychospołeczne aspekty kryzysu. SWSPiZ, Łódź: $179-196$.

Świtaj P. (2005). Piętno choroby psychicznej. „Postępy Psychiatrii i Neurologii”, 14, 2: 137-144.

Tobiasz-Adamczyk B. (2000). Wybrane elementy socjologii zdrowia i choroby. Wydawnictwo Uniwersytetu Jagiellońskiego, Kraków.

Tobiasz-Adamczyk B. (2002). Relacje lekarz-pacjent w perspektywie socjologii medycyny. Wydawnictwo Uniwersytetu Jagiellońskiego, Kraków.

Wciórka B., Wciórka J. (2008). Osoby chore psychicznie w społeczeństwie. Komunikat z badań. CBOS, Warszawa.

Williams C.C. (2008). Insight stigma, and post-diagnosis identities in schizophrenia. „Psychiatry”, 71, 3: 246-256. 